\title{
Longitudinal variation characteristics of stable isotope ratios of suspended particulate organic matter in the headwaters of the Qingjiang River, China
}

\author{
Jian Gao ${ }^{1, *}$, Zehui Zhang ${ }^{1}$, Ping Zhong ${ }^{2}$, Cheng Yang ${ }^{1}$, Mingjun Liao ${ }^{1}$ and Yiying Jiao ${ }^{1}$ \\ ${ }^{1}$ Hubei Province Key Laboratory of Ecological restoration of Lakes and Rivers and Algal Utilization, School of Civil and Environmental \\ Engineering, Hubei University of Technology, Wuhan 430068, PR China \\ ${ }^{2}$ Department of Ecology and Institute of Hydrobiology, Tropical and Subtropical Aquatic Ecological Engineering Center of the Ministry \\ of Education of China, Jinan University, Guangzhou 510630, PR China
}

Received: 5 December 2020 / Accepted: 3 February 2021

\begin{abstract}
To determine the sources and characteristics of suspended particulate organic matter (SPOM), the spatial distribution of carbon and nitrogen and their isotopic values $\left(\delta^{13} \mathrm{C}\right.$ and $\left.\delta^{15} \mathrm{~N}\right)$ were measured from upstreamto downstream (i.e. site 1 to site 4 ) in the head waters of the Qingjiang River in central China. The mean annual SPOM $\delta^{15} \mathrm{~N}$ and $\delta^{13} \mathrm{C}$ values varied between sites but exhibited a unimodal pattern. The mean annual $\delta^{15} \mathrm{~N}$ increased from site $1(2.5 \%)$ to $3(5.3 \%$ ), followed by a major decrease to $2.2 \%$ at site 4 . Furthermore, the mean annual $\delta{ }^{13} \mathrm{C}$ varied unimodally, being the most positiveat sites $1(-21.6 \%)$ and 4 $(-22.8 \%)$ followed by sites $2(-24.5 \%)$ and $3(-26.4 \%)$. In particular, the mean SPOM $\delta^{15} \mathrm{~N}$ and $\delta^{13} \mathrm{C}$ in the tailwaters from a domestic wastewater treatment plant, which was located approximately $0.3 \mathrm{~km}$ upstream of site 4 , were $2.2 \%$ and $-25.6 \%$, respectively. The SPOM C/N values from stream water at site 4 $(8.5 \pm 1.5)$ and tailwater $(6.2 \pm 0.9)$ were similar. Collectively, the results suggested that wastewater treatment plant tailwater influenced the stable isotope values of SPOM in the stream and affected the variation trendfrom upstream to downstream.
\end{abstract}

Keywords: Suspended particulate organic matter / stream / stable isotope / anthropogenic pollution / tailwater

Résumé - Caractéristiques de la variation longitudinale des rapports d'isotopes stables de la matière organique particulaire en suspension dans les eaux d'amont du fleuve Qingjiang, Chine. Afin de déterminer les sources et les caractéristiques des particules organiques en suspension (SPOM), la distribution spatiale du carbone et de l'azote et leurs valeurs isotopiques $\left(\delta^{13} \mathrm{C}\right.$ and $\left.\delta^{15} \mathrm{~N}\right)$ ont été mesurées d'amont en aval (c'est-à-dire du site 1 au site 4) dans le cours supérieur du fleuve Qingjiang, en Chine centrale. Les valeurs annuelles moyennes $\delta^{15} \mathrm{~N}$ et $\delta^{13} \mathrm{C}$ de la SPOM variaient d'un site à l'autre, mais présentaient un schéma unimodal. La moyenne annuelle de $\delta^{15} \mathrm{~N}$ a augmenté du site $1(2,5 \%)$ à $3(5,3 \%)$, suivie d'une baisse importante à $2,2 \%$ sur le site 4 . En outre, la moyenne annuelle de $\delta^{13} \mathrm{C}$ a varié de manière unimodale, étant la plus positive sur les sites $1(-21.6 \%)$ et $4(-22.8 \%)$, suivie par les sites $2(-24.5 \%)$ et $3(-26.4 \%)$. En particulier, les moyennes $\delta^{15} \mathrm{~N}$ et $\delta^{13} \mathrm{C}$ des SPOM dans les eaux résiduaires d'une station d'épuration des eaux usées domestiques, qui était située à environ $0,3 \mathrm{~km}$ en amont du site 4 , étaient respectivement de $2,2 \%$ et $-25,6 \%$. Les $\mathrm{C} / \mathrm{N}$ valeurs des SPOM des eaux de ruissellement du site $4(8,5 \pm 1,5)$ et des eaux résiduaires $(6,2 \pm 0,9)$ étaient similaires. Collectivement, les résultats suggèrent que les eaux résiduaires des stations d'épuration des eaux usées influencent les valeurs isotopiques stables de SPOM dans le cours d'eau et affectent la tendance de variation d'amont en aval.

Mots clés : Matière organique particulaire en suspension / cours d'eau / isotope stable / pollution anthropique / eaux résiduaires

\footnotetext{
*Corresponding author: jgao13@hotmail.com
} 
Suspended particulate organic matter (SPOM) is an important component of stream systems and is a major pathway of organic matter transport and export in a watershed (Ulseth and Hershey, 2005; Lambert et al., 2017). SPOM is derived from various sources, including autochthonous algae and aquatic plants, allochthonous terrestrial plants, and faecal and animal detritus (Cummins, 1974; Ngugi et al., 2017; Hou et al., 2019).

The stable $\mathrm{C}$ isotopic values of SPOM can indicate primary productivity and $\mathrm{CO}_{2}$ concentration $(\mathrm{Gu}$ et al., 2006) and track the sources of organic matter (Gu et al., 2011; Hou et al., 2019). The stable $\mathrm{N}$ isotopic values of SPOM has been used to help understand various nitrogen cycling processes such as dissolved inorganic nitrogen (DIN) uptake and nitrogen fixation ( $\mathrm{Gu}$ et al., 2006) and anthropogenic pollution (Ke et al., 2017; Lambert et al., 2017) in aquatic environments. In general, stoichiometric $\mathrm{C} / \mathrm{N}$ ratios of SPOM are higher for allochthonous terrestrial plants than for algae and aquatic plants (Anderson and Sedell, 1979; Atkinson et al., 2009; Lu et al., 2014). In addition, anthropogenic organic matter tends to increase the $\delta^{15} \mathrm{~N}$ values of aquatic organisms. The nitrate $\delta^{15} \mathrm{~N}$ value of air is close to $0 \%$, whereas those of septic water, wastewater, and manure are high, varying from $10 \%$ to 22\% (McClelland and Valiela, 1998; Anderson and Cabana, 2006). Longitudinal variations in the $\delta^{15} \mathrm{~N}$ characteristics of stream POM can be used to identify $\mathrm{N}$ sources in waterways because they provide information on the $\mathrm{N}$ source and major biogeochemical processes in aquatic ecosystems (Vander Zanden et al., 2005; Finlay and Kendall, 2007; Ryu et al., 2018; Xuan et al., 2019). So the stable $\mathrm{C}$ and $\mathrm{N}$ isotopic values and $\mathrm{C} / \mathrm{N}$ ratios of SPOM have been widely used in aquatic biogeochemistry to identify the sources (terrestrial, freshwater, or marine) and fate of organic matter in aquatic ecosystems based on their unique range of values for different sources (Kendall et al., 2001; Usui et al., 2006; Jha and Masao, 2013).

The Qingjiang River, a subtropical river in Enshi, Hubei Province, Central China, is the first large tributary and water source protection zone in the middle of the Yangtze River after it passes through the Three Gorges Dam (China GEBE, 1993; Cao and Yang, 2015). A distinct longitudinal pattern was observed in the nutrient levels in the Qingjiang River's headwater stream (Liu et al., 2018). Tolerance sensibility of benthic macroinvertebrates along water flow direction was decreased from the mountains (upstream) to urban (downstream) sites in the Qingjiang River's headwater stream, indicating water quality degradation as anthropogenic pollution (Pan et al., 2018). Our study aimed to determine variations in the stable isotopes of $\mathrm{C}$ and $\mathrm{N}$ from upstream to downstream in the head waters of the Qingjiang River. We hypothesised that the $\delta^{15} \mathrm{~N}$ values would increase, whereas $\delta^{13} \mathrm{C}$ values would decrease from upstream to downstream as the river is influenced by human activities with associated pollutions.

The total length of this river is $423 \mathrm{~km}$ (Cao and Yang, 2015), and the headwater stream of this river selected for this study was approximately $76.8 \mathrm{~km}$. Samples were collected from upstream to downstream at four sites (sites 1-4; Fig. 1). Site 1, the most upstream site, was located in a sparsely populated residential area and is considered the most pristine site because the riparian vegetation consists of intact shrubs and forests (Tab. 1; Liu et al., 2018). Site 2 was located in the middle of a village. The dominant land used here was for fields and residence, and the site was therefore likely contaminated with manure, farmland fertiliser, and other materials. Site 3 was located downstream of Wangying town, which has a population of approximately 25000 but no wastewater treatment plant. Site 4 was located downstream of Lichuan City, which has a population of approximately 66000 people and a wastewater treatment plant situated approximately $0.3 \mathrm{~km}$ upstream. Tailwater from this treatment plant flows into the river (Tab. 1; Liu et al., 2018). The sewage treatment plant was built in 2010 and uses an oxidation ditch process.

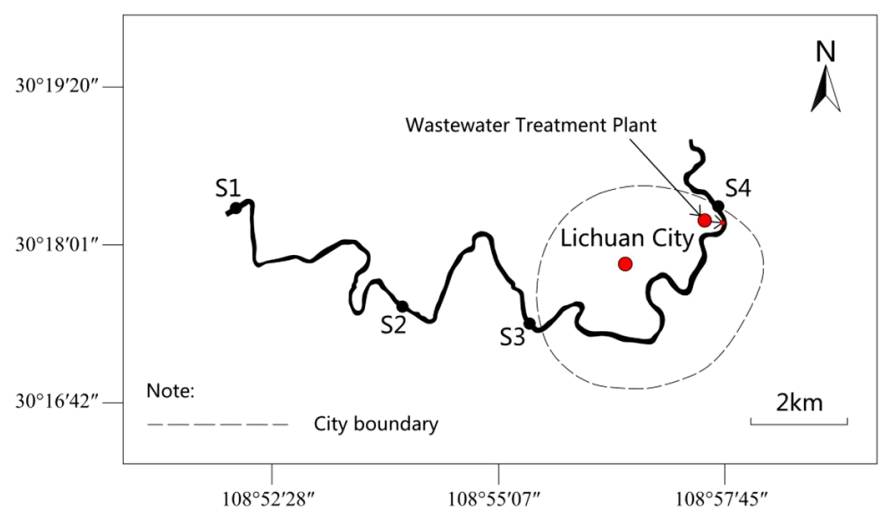

Fig. 1. Location of sampling sites in the headwater stream of the Qingjiang River. S1 to S4 denote sampling sites 1 to 4 . Wastewater treatment plant located approximately $0.3 \mathrm{~km}$ upstream of the sampling site 4 . Tailwater flowed into the stream.

Table 1. Features of sampling sites in the headwater stream of the Qingjiang River.

\begin{tabular}{lllll}
\hline Sites & Land use type & $\begin{array}{l}\text { Distance from the } \\
\text { fountainhead }(\mathrm{km})\end{array}$ & $\begin{array}{l}\text { Land used for urban, rural, } \\
\text { industrial, mining, and } \\
\text { residential purpose }\left(\mathrm{km}^{2}\right)\end{array}$ & Description \\
\hline 1 & Intact shrubs and forests & 0.75 & 0.33 & $\begin{array}{l}\text { The most upstream site on the stream transect } \\
\text { was located in a sparsely populated area. } \\
\text { Potentially contaminated with manure, farmland } \\
\text { fertiliser, and other materials. } \\
\text { Potentially contaminated with manure, farmland } \\
\text { fertiliser, and other materials. } \\
\text { Wastewater treatment plant located } \\
\text { approximately } 0.3 \mathrm{~km} \text { upstream of the sampling } \\
\text { site. Tailwater flowed into the stream. }\end{array}$ \\
\hline & Fields and village & 18.25 & 1.0 & 4.64 \\
\hline
\end{tabular}


The plant treats 20000 tons of wastewater per day. The chemical oxygen demand $\left(\mathrm{COD}_{\mathrm{Cr}}\right)$, total nitrogen $(\mathrm{TN})$, ammonia-nitrogen, and total phosphorus (TP) concentrations of wastewater discharge are $60,20,8$ (or $15 \mathrm{mg} / \mathrm{L}$ when the temperature is $<12^{\circ} \mathrm{C}$ ), and $1.5 \mathrm{mg} / \mathrm{L}$, respectively (China EPA, 2002).

Sampling was conducted bimonthly in odd-numbered months from May 2016 to March 2017. Water temperature (WT) was measured using a YSI metre (YSI ProPlus, Yellow Springs, OH, USA). Water samples for chemical and chlorophyll $a(\mathrm{Chl} a)$ were collected at $0.5-\mathrm{m}$ depth below the water surface (surface water collected if the depth is $<0.5 \mathrm{~m}$ ) from three stations at each site and pooled. Approximately $2.5 \mathrm{~L}$ of water was stored in a cooling box and transported to the laboratory where it was analysed according to standard methods (China EPA, 2009), basically corresponding with US standards (APHA, 1998). The Chla concentration was determined spectrophotometrically after sample filtration through cellulose acetate filters and extraction of the filtered materialswith $90 \%$ acetone; TP and TN concentrations were determined spectrophotometrically after digestion with persulphate; the potassium permanganate method was used to determine the chemical oxygen demand $\left(\mathrm{COD}_{\mathrm{Mn}}\right)$ (China EPA, 2009).

To analyse the stable isotope composition of SPOM in stream water and tailwater from domestic wastewater treatment plants, water was passed through precombusted GF/F filters, which were subsequently freeze dried. All stable isotope samples were stored in a desiccator containing dried allochroic silica gel before analysis. Thereafter, all samples were analysed using a Vario PYRO Cube elemental analyser coupled to anIsoprime-100 isotope ratio mass spectrometer at the Environmental Stable Isotope Laboratory, Chinese Academy of Agriculture Sciences. Stable isotope ratios are expressed in the delta $(\delta)$ notation, defined as parts per thousand deviations from a certified standard; $\delta{ }^{13} \mathrm{C}$ or $\left.\delta^{15} \mathrm{~N}=\left(\left[R_{\text {sample }} / R_{\text {standard }}\right]\right)-1\right) \times 1000$, where $R$ is the ratio of ${ }^{13} \mathrm{C} /{ }^{12} \mathrm{C}$ or ${ }^{15} \mathrm{~N} /{ }^{14} \mathrm{~N}$. The standards for $\delta^{13} \mathrm{C}$ and $\delta^{15} \mathrm{~N}$ were a secondary standard of known relation to the international standard of VPDB and atmospheric nitrogen, respectively. The standard errors of the mean for replicates of the same tissue were $0.2 \%$ for $\delta^{13} \mathrm{C}$ and $0.2 \%$ for $\delta^{15} \mathrm{~N}$.

For statistical analyses, we used SPSS 19.0 for Windows, and all data sets were examined for normality and transformed when needed using $\ln (\mathrm{x})$ before analyses (Box and Cox, 1964). Spearman correlation analysis was used to determine significant correlations between physicochemical factors and stable isotope parameters. The differences in physicochemical factors and stable isotope parameters between sites were assessed using repeated-measures analysis of variance (ANOVA) with time as the repeated factor. If a significant difference was noted, Tukey's Multiple Comparison Test post hoc tests were used to detect which treatments differed. Before performing ANOVA, we tested whether the data met the assumptions of homogeneity of variances by using Levene's test. If the assumption was not met, then we used KruskalWallis nonparametric ANOVA.

The WTs were $16.5^{\circ} \mathrm{C}$ in May $2016,20.7^{\circ} \mathrm{C}$ in July 2016, $18.4^{\circ} \mathrm{C}$ in September $2016,9.9^{\circ} \mathrm{C}$ in November $2016,6.1^{\circ} \mathrm{C}$ in January 2017 , and $9.6^{\circ} \mathrm{C}$ in March 2017 . The mean annual

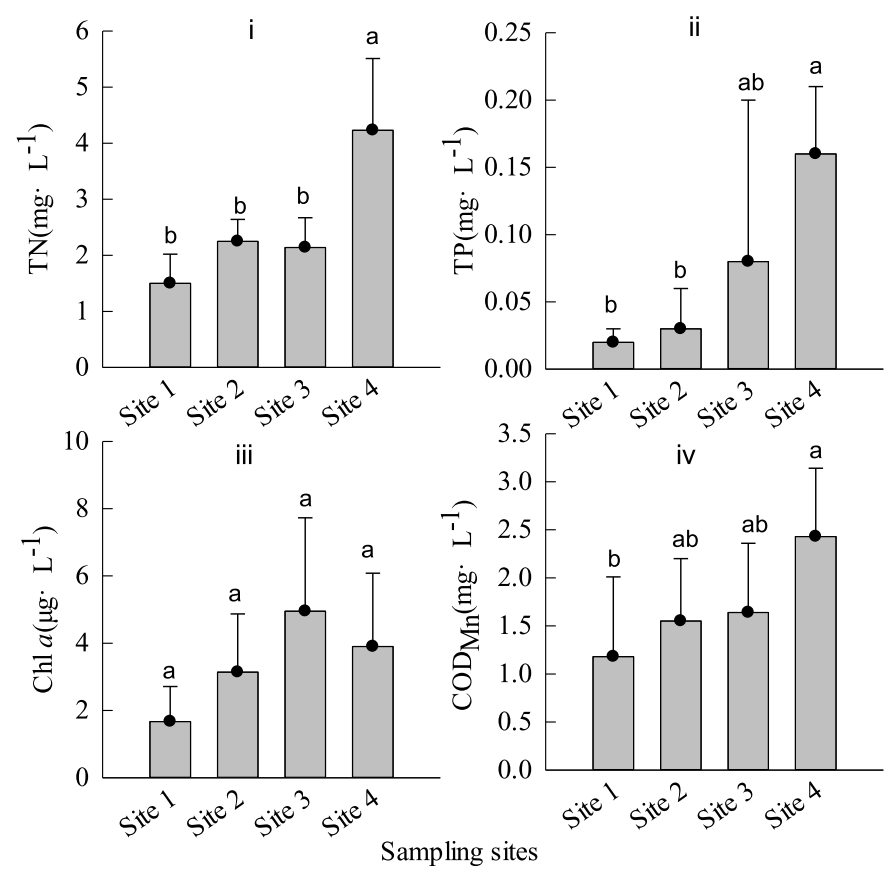

Fig. 2. Chemical and biological characteristics of the headwater stream of the Qingjiang River (mean \pm standard deviation). Vertical lines indicate standard deviation. Figure i, ii, iii and iv denote TN, TP, $\mathrm{Chl} a$ and $\mathrm{COD}_{\mathrm{Mn}}$ concentrations, respectively. Letters a and $\mathrm{b}$ indicate significant $(p<0.05)$ differences for physicochemical factors. Sampling sites that do not have a significantly different concentrations share a common letter.

concentrations of $\mathrm{TN}$ and $\mathrm{TP}$ increased from upstream to downstream (Fig. 2i, ii). TN concentrations did not differ significantly between sites $1-3$, whereas it increased markedly to $4.23 \mathrm{mg} \cdot \mathrm{L}^{-1}$ at site 4 (one-way ANOVA, Tukey's Multiple Comparison, $p<0.01$; Fig. $2 \mathrm{i}$ ). TP concentrations ranged from 0.02 to $0.16 \mathrm{mg} \cdot \mathrm{L}^{-1}$, and higher at site 4 than at site 1 and 2 (one-way ANOVA, Tukey's Multiple Comparison, $p<0.05$, Fig. 2ii). Chla concentrations were low at all sites, ranging from 1.7 to $5.0 \mu \mathrm{g} \cdot \mathrm{L}^{-1}$ (Fig. 2iii). $\mathrm{COD}_{\mathrm{Mn}}$ concentration was higher at site 4 than at site 1 (one-way ANOVA, Tukey's Multiple Comparison, $p<0.05$, Fig. 2ii), but low values were recorded at all sites (Fig. 2iv). The high mean concentrations of $\mathrm{TN}, \mathrm{TP}$, and $\mathrm{COD}_{\mathrm{Mn}}$ observed at downstream sites 2 and 3 were probably due to the nutrient contributions from village and town wastewater, agricultural areas, and livestock farming areas (Tab. 1) as by Liu et al. (2018). The high annual mean concentrations of TN observed at site 4 were probably due to the nutrient contributions from the wastewater treatment plants tailwater (Tab. 1, Fig. 1). Similar studies suggested that discharge from the domestic wastewater treatment plant played a crucial role in affecting nutrients dynamics of stream (Tachibana et al., 2001; Jha and Masao, 2013).

The mean $\delta^{15} \mathrm{~N}$ value at upstream locations increased from site 1 to site 3 , ranging from $2.4 \%$ to $5.3 \%$, but decreased to $2.2 \%$ at site 4 (Fig. $3 \mathrm{i}$ ). The SPOM $\delta{ }^{15} \mathrm{~N}$ values increased from site 1 to site 3 from upstream to downstream, reflecting anthropogenic nitrogen pollution. The primary sources of anthropogenic nitrogen were sites 2 and 3 in the form of waste 

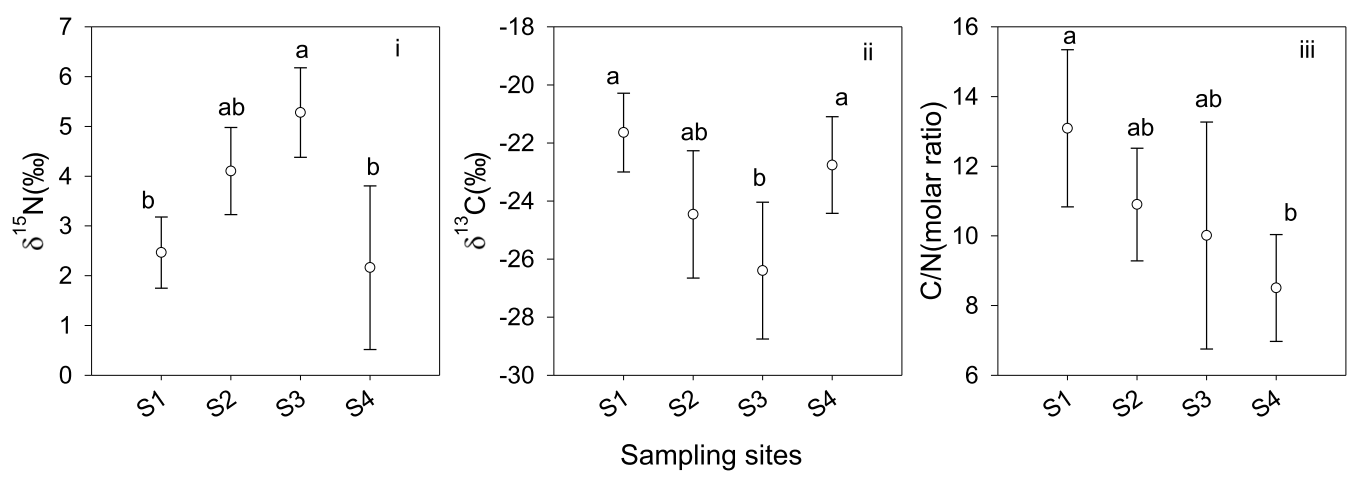

Fig. 3. Mean annual SPOM $\delta^{13} \mathrm{C}, \delta^{15} \mathrm{~N}$, and molar $\mathrm{C} / \mathrm{N}$ ratio in the headwater stream of the Qingjiang River. Vertical bars indicate standard deviations. Figure i, ii and iii denote SPOM $\delta{ }^{13} \mathrm{C}$ values, $\delta^{15} \mathrm{~N}$ values, and molar $\mathrm{C} / \mathrm{N}$ ratio, respectively. Letters a, $\mathrm{b}$, and $\mathrm{c}$ indicate significant $(p<0.05)$ differences for $\delta^{13} \mathrm{C}, \delta^{15} \mathrm{~N}$, and $\mathrm{C} / \mathrm{N}$ ratio. Sampling sites that do not have significantly different values share a common letter.

from livestock farming, and sanitary wastewater. The effluents are routinely discharged directly into the stream without any treatment. Hence, increases in SPOM $\delta^{15} \mathrm{~N}$ at downstream locations may be attributable to nitrogen pollution from anthropogenic organic matter. Furthermore, Toda et al. (2002) and Ning et al. (2013) have reported a significant positive relationship between the SPOM and periphyton $\delta^{15} \mathrm{~N}$ values and the percentage contribution to nitrogen loading from sewage and livestock waste. However, in the present study, unexpectedly, the SPOM $\delta^{15} \mathrm{~N}$ drastically decreased at site 4 , with high concentrations of TN and TP, which was situated close to the wastewater treatment plant (only $0.3 \mathrm{~km}$ at the upstream location of site 4$)$. The $\delta^{15} \mathrm{~N}$ values of stream water at site $4(2.2 \%$ $\pm 1.6 \%$ ) (Fig. $3 i)$ and wastewater treatment plant tailwater $(2.2 \% \pm 0.6)$ were similar in our studies. Previous studies reported that isotopic values of sewage solids varied in terms of $\delta^{15} \mathrm{~N}$ (mean, $+3.2 \%$; range -1.1 to $+7.2 \% ; n=7$ ) (Van Dover et al., 1992; Gearing et al., 1991, 1994; Andrews et al., 1998; Ulseth, 2003). Our results suggested that that sewage solids from tailwater contributed to the SPOM composition at site 4 .

Additionally, we noted that the SPOM $\delta^{13} \mathrm{C}$ varied unimodally; it was most positive at site $1(-21.6 \%$ t $1.4 \%$ ), with low concentrations of TN and TP, and at site 4 $(-22.8 \% \pm \pm 1.7 \%$ ) , with higher concentrations of $\mathrm{TN}$ and $\mathrm{TP}$ than at the other two sites (Fig. 3ii). Kendall et al. (2001) indicated that the $\delta^{13} \mathrm{C}$ values of $\mathrm{C} 3$ plants, $\mathrm{C} 4$ plants, and fresh water phytoplankton are $-27 \%$ o $(-32 \%$ to $-22 \%$ o $),-13 \%$ o $(-16 \%$ to $-9 \%)$, and $-30 \%$ ( $-42 \%$ to $-24 \%)$, respectively. The SPOM $\delta^{13} \mathrm{C}$ in the headwater stream of the Qingjiang River ranged from $-29.1 \%$ o to $-20.2 \%$ (Fig. 3ii), suggesting that most of the SPOM in the stream system is governed by Rubisco-mediated photosynthesis (Calvin cycle), but the contributions from C4-based (Hatch-Slack cycle) vascular plant organic matter might also be important. Particularly at site 1, maize (C4 plant) production on both sides of the stream may result in detritus entering the adjacent stream ecosystems, yielding high $\delta{ }^{13} \mathrm{C}$ values. The $\delta{ }^{13} \mathrm{C}$ values decreased from site 1 to site 3 , suggesting that the contribution from instream algae sources gradually increased, whereas that from terrestrial sources decreased (Fig. 3ii). However, this observed trend in $\delta^{13} \mathrm{C}$ values changed at site 4 (Fig. 3ii). The mean $\delta{ }^{13} \mathrm{C}$ values of SPOM were lower $(-25.6 \% \pm 1.9 \%)$ in tailwater from domestic wastewater treatment plants than at site 4 $\left(-22.8 \% \%_{0} \pm 1.7 \%\right.$ in our study. However, other studies reported that isotopic values of sewage solids varied in terms of $\delta^{13} \mathrm{C}$ (mean, $-23.4 \%$; range $-28.5 \%$ to $-16.5 \%$; $n=13$; Gearing et al., 1991, 1994; Van Dover et al., 1992; Andrews et al., 1998). The $\delta^{13} \mathrm{C}$ value of sewage-effected SPOM collected from site 4 in our study $(-22.8 \%$ ) was similar to the literature mean value (-23.4\%) (Gearing et al., 1991, 1994; Van Dover et al., 1992; Andrews et al., 1998).

Carbon to nitrogen ratios can be also used to identify organic matter sources because the molar $\mathrm{C} / \mathrm{N}$ ratios of plankton and bacteria (6-7 and 4-5, respectively) are much lower than those of organic matter derived from higher plants (>20; Hedges et al., 1997; Sarma et al., 2012). The molar C/N ratio of SPOM was between 6.7 and 17.6 (Fig. 3iii), with a higher ratio observed in the upper stream $(13.1 \pm 2.3)$ than in the lower stream $(8.5 \pm 1.5)$. Molar $\mathrm{C} / \mathrm{N}$ ratio were also significantly negatively correlated with Chla $(p<0.05$, $n=24)$. However, the SPOM C/N ratios were similar between stream water at site $4(8.5 \pm 1.5)$ and tailwater $(6.2 \pm 0.9)$ in our study, suggesting that sewage solids from tailwater contributed to the composition of SPOM at site 4 . Thus, these results suggested the organic matter derived from terrestrial organic matter decreased and that from plankton or bacteria increased from site 1 to site 4 .

Overall, our results revealed that nutrient input increased from upstream to downstream in the headwater stream of the Qingjiang River; however, variations in SPOM $\delta{ }^{15} \mathrm{~N}$ and $\delta{ }^{13} \mathrm{C}$ between sites exhibited a unimodal pattern unlike variation in nutrient concentrations. The variations in the SPOM $\delta^{15} \mathrm{~N}$ exhibited no correlation with TN and TP concentrations ( $p>0.05, n=24)$, suggesting that different processes affect the $\delta^{15} \mathrm{~N}$ isotopic values of SPOM samples. The unimodal variations in the SPOM $\delta^{13} \mathrm{C}$ and the negative correlations between molar $\mathrm{C} / \mathrm{N}$ ratio and $\mathrm{Chl} a$ concentration suggested that organic matter derived from terrestrial organic matter decreased and that from plankton or bacteria increased from upstream to downstream. These results suggested the tailwater from the wastewater treatment plant affected the positive relationship between the SPOM $\delta{ }^{15} \mathrm{~N}$ value and the percentage contribution to nitrogen loading from sewage and livestock waste.

Acknowledgments. The authors thank Linfeng Liu, Chao Pan, Cheng Liu for field and laboratory support. This manuscript 
was edited by Wallace Academic Editing. This study was supported by the National Natural Science Foundation of China (Grant No. 31500378, 91647207, 31670367), by Nature Science Foundation of Hubei Province (2020CFB537) and by major project ofScience and Technology Department of Hubei Province (2018ZYYD037).

\section{References}

Anderson NH, Sedell JR. 1979. Detritus processing by macroinvertebrates in stream ecosystems. Annu Rev Entomol 24: 351-377

Anderson C, Cabana G. 2006. Does $\delta^{15} \mathrm{~N}$ in river food webs reflect the intensity and origin of $\mathrm{N}$ loads from the watershed? Sci Total Environ 367: 968-978.

Andrews JE, Greenaway AM, Dennis PF. 1998. Combined carbon isotope and $\mathrm{C} / \mathrm{N}$ ratios as indicators of source and fate of organic matter in a poorly flushed, tropical estuary: Hunts Bay, Kingston Harbour, Jamaica. Estuar Coast Shelf Sci 46: 743-756.

APHA. 1998. Standard methods for the examination of water and wastewater, 20th ed. Washington, DC: American Public Health Association.

Atkinson CL, Golladay SW, Opsahl SP, Covich AP. 2009. Stream discharge and floodplain connections affect seston quality and stable isotopic signatures in a coastal plain stream. $J N$ Am Benthol Soc 28: 360-370.

Box GEP, Cox DR. 1964. An analysis of transformations. J R Stat Soc 26: 211-252.

Cao S, Yang L. 2015. Study on Comprehensive Treatment of the Water Pollution of Qingjiang River Basin's Tourism Environment. Ecol Econ 31: 141-143 (in Chinese).

Cummins KW. 1974. Structure and Function of Stream Ecosystems. BioScience 24: 631-641.

China EPA. 2002. Chinese Discharge Standard for Pollutants from Urban Sewage Treatment Plants (GB18918-2002). PRC National Standard (in Chinese).

China EPA. 2009. Water and wastewater monitoring and analysis methods, 4th ed. China Environmental Science Press (in Chinese).

Finlay JC, Kendall C. 2007. Stable isotope tracing of temporal and spatial variability in organic matter sources to freshwater ecosystems. In: Michener RH, Lajtha K, ed., Stable Isotopes in Ecology and Environmental Science. Blackwell Publishing, pp. 283-333.

Gearing PJ, Gearing JN, Maughan J, Oviatt CA. 1991. Isotopic distribution of carbon from sewage sludge and eutrophication in the sediments and food web of estuarine ecosystems. Environ Sci Technol 25: 295-301.

Gearing JN, Tronczynski J, Macko SA. 1994. Particulate organic matter in the St. Lawrence Estuary: anthropogenic and natural sources. In Dyer KR, Orth RJ, eds. Changes in Fluxes in Estuaries: Implications from Science to Management. Fredensborg: Olsen and Olsen, pp. 125-130.

General Editorial Board of Encyclopedia of China (China GEBE). 1993. Encyclopedia of China-China Geography. Encyclopedia of China Publishing House (in Chinese).

Gu B, Chapman AD, Schelske CL. 2006. Factors controlling seasonal variations in stable isotope composition of particulate organic matter in a soft water eutrophic lake. Limnol Oceanogr 51: 2837-2848.
Gu B, Schelske CL, Waters MN. 2011. Patterns and controls of seasonal variability of carbon stable isotopes of particulate organic matter in lakes. Oecologia 165: 1083-1094.

Hedges JI, Keil RG, Benner R. 1997. What happens to terrestrial organic matter in the ocean? Org Geochem 27: 195-21.

Hou W, Sun S, Wang M, Gu B, Li X, Zhang C, Jia R. 2019. Variations in stable carbon and nitrogen isotopes of particulate organic matter in surface waters of water-receiving area of Eastern Route of South-to-North Water Transfer Project, China. Environ Sci Pollut Res 27: 2805-2818.

Jha PK, Masao M. 2013. Factors affecting nutrient concentration and stable carbon and nitrogen isotope ratio of particulate organic matter in the Ishikari river system, Japan. Water Air Soil Pollut 224: $1-22$.

Ke Z, Tan Y, Huang L, Zhao C, Jiang X. 2017. Spatial distributions of $\delta{ }^{13} \mathrm{C}, \delta^{15} \mathrm{~N}$ and $\mathrm{C} / \mathrm{N}$ ratios in suspended particulate organic matter of a bay under serious anthropogenic influences: Daya bay, China. Mar Pollut Bull 114: 183-191.

Kendall C, Silva SR, Kelly VJ. 2001. Carbon and nitrogen isotopic compositions of particulate organic matter in four large river systems across the United States. Hydrol Process 15: 1301-1346.

Lambert T, Bouillon S, Darchambeau F, Morana C. Rolandb FAE, Descy JP, Borges AV. 2017. Effects of human land use on the terrestrial and aquatic sources of fluvial organic matter in a temperate river basin (The Meuse River, Belgium). Biogeochemistry 136: 191-211.

Liu LF, Pan C, Zhou C, Miao T, Xiong W, Liu W, Li Z, Xu D, Zhao Yj, Gao J. 2018. Macrozoobenthic community spatial structure and water quality bioassessment in Lichuan reach, the Qingjiang river, China. J Hydroecol 39: 39-46 (in Chinese).

Lu YH, Canuel EA, Bauer JE, Chambers RM. 2014. Effects of watershed land use on sources and nutritional value of particulate organic matter in temperate headwater streams. Aquat Sci 76: 419-436.

McClelland JW, Valiela I. 1998. Linking nitrogen in estuarine producers to land-derived sources. Limnol Oceanogr 43: 577-585.

Ngugi CC, Oyoo-okoth E, Gichuki J, Gatune G, MwangiKinyanjui J. 2017. Fingerprints of upstream catchment land use in suspended particulate organic matter (SPOM) at the river discharge sites in Lake Victoria (Kenya): insights from element, stable isotope and lipid biomarker analysis. Aquat $\mathrm{Sci}$ 79: 73-87.

Ning J, Zhang H, Li X, Zhong P, Tang Y, Liu Z. 2013. Characteristics of stable nitrogen isotopes in particulate organic matter and periphyton of a subtropical Chinese watercourse, the Dashahe River. Knowl Manag Aquat Ecosyst 410: 1-5.

Pan C, Zhou C, Miao T, Liu L, Gao J, Jiao Y, Li Z, Zhang J, Wang H, $\mathrm{Xu}$ D. 2018. Macrozoobenthic community structure and water quality bioassessment of four rivers in Western Hubei Province, Yangtze River Basin. Res Environ Yangtze Bas 27: 2529-2539 (in Chinese).

Ryu HD, Kim MS, Chung EG, Baek UI, Kim SJ, Kim DW, Kim YS, Lee JK. 2018. Assessment and identification of nitrogen pollution sources in the Cheongmi River with intensive livestock farming areas, Korea. Environ Sci Poll Res 25: 13499-13510.

Sarma VVSS, Arya J, Subbaiah CV, Naidu SA, Gawade L, Kumar PP, Reddy NPC. 2012. Stable isotopes of carbon and nitrogen in suspended matter and sediments from the godavari estuary. J Oceanogr 68: 307-319. 
Tachibana H, Yamamoto K, Yoshizawa K, Magara Y. 2001. Non-point pollution of Ishikari River, Hokkaido, Japan. Water Sci Technol 44: 1-8.

Toda H, Uemura Y, Okino T, Kawanishi T, Kawashima H. 2002. Use of nitrogen stable isotope ratio of periphyton for monitoring nitrogen sources in a river system. Water Sci Technol 46: 431-435.

Ulseth AJ. 2003. Use of the natural abundance of $15 \mathrm{~N}$ to evaluate the effects of anthropogenic $\mathrm{N}$ on the components of a headwater urban stream. MS Thesis, University of North Carolina Greensboro, Greensboro, North Carolina.

Ulseth AJ, Hershey AE. 2005. Natural abundances of stable isotopes trace anthropogenic $\mathrm{N}$ and $\mathrm{C}$ in an urban stream. $J$ N Am Benthol Soc 24: 270-289.
Usui T, Nagao S, Yamamoto M, Suzuki K, Kudo I, Montani S, Noda A, Minagawa M. 2006. Distribution and sources of organic matter in surficial sediments on the shelf and slope off Tokachi, western North Pacific, inferred from $\mathrm{C}$ and $\mathrm{N}$ stable isotopes and $\mathrm{C} / \mathrm{N}$ ratios. Mar Chem 98: 241-259.

Van Dover CL, Grassle JF, Fry B, Garritt RH, Starczak VR. 1992. Stable isotope evidence for entry of sewage-derived organic material into a deep-sea food web. Nature 360: 153-156.

Vander Zanden MJ, Vadeboncoeur Y, Diebel MW, Jeppesen E. 2005. Primary consumer stable nitrogen isotopes as indicators of nutrient source. Environ Sci Technol 39: 7509-7515.

Xuan Y, Tang C, Cao Y, Li R, Jiang T. 2019. Isotopic evidence for seasonal and long-term $\mathrm{C}$ and $\mathrm{N}$ cycling in a subtropical basin of southern China. J Hydrol 577: 123926.

Cite this article as: Gao J, Zhang Z, Zhong P, Yang C, Liao M, Jiao Y. 2021. Longitudinal variation characteristics of stable isotope ratios of suspended particulate organic matter in the headwaters of the Qingjiang River, China. Knowl. Manag. Aquat. Ecosyst., $422,7$. 